DOI https://doi.org/10.30525/978-9934-588-80-8-2.63

\title{
АНАЛІЗ СКЛАДОВИХ АНДРАГОГІЧНОЇ МОДЕЛІ ОРГАНІЗАЦІЇ ПРОФЕСІЙНОЇ ПІДГОТОВКИ ЗДОБУВАЧІВ ВИЩОЇ ОСВІТИ
}

\author{
Семенова О. Ю. \\ аспірантка кафедри педагогіки \\ Одеський національний університет імені I. І. Мечникова \\ м. Одеса, Україна
}

Тенденції розвитку загальноєвропейського освітнього простору, а також чинники інтеграції та уніфікації форм, змісту та рівнів вищої освіти, вимагають приведення освітньо-кваліфікаційних рівнів підготовки випускників вищих навчальних закладів у відповідність до нових вимог. Останні, завдяки модернізаційним перетворенням й трансформації національної системи вищої освіти в контексті вимог європейської рамки кваліфікацій, орієнтують вищі навчальні заклади на здійснення якісної підготовки здобувачів за першим - бакалаврським, другим - магістерським та третім - освітньо-науковим рівнями.

Суттєво й те, що в умовах інтенсивного розвитку науково-технічного прогресу право та відповідальність за накопичення, акумулювання та передачу знань переходить від експертів до окремих членів сучасного суспільства, які не тільки мають можливість, але й зобов'язані робити вибір ролі освіти у процесі своєї життєдіяльності. Зумовлено це тим, що освіта як сфера життєдіяльності особистості в іiі антропологічному розумінні, дозволяє забезпечити реалізацію освітніх завдань на основі розвитку іiі освітніх потреб не тільки в цілях професійної самореалізації, але й придбання психологічного комфорту, розвитку та задоволення власних культурних, дозвіллєвих та інших орієнтацій. Практичне втілення антропологічної концепції актуалізує тезис Е. Фора «навчатися, щоб бути» [2, с. 91], дозволяючи в умовах здобуття вищої освіти здійснити перехід від знаннєвої парадигми до розвивальної - особистісно та практико зорієнтованої. Останні дозволяють інтенсивно застосувати провідні принципи андрагогічного підходу [1, с. 49], а також розробляти андрагогічні моделі організації професійної підготовки здобувачів вищої освіти, оскільки вони, за своїми соціопсихологічними параметрами, $є$ дорослими й достатньо «зрілими» суб'єктами освітнього процесу. 
Мета статті полягає у висвітленні провідних складових андрагогічної моделі організації професійної підготовки здобувачів вищої освіти.

При розробці андрагогічної моделі ми виходили 3 того, що необхідною умовою успішної організації професійної підготовки здобувачів вищої освіти як цілісної, динамічної та відкритої педагогічної системи $є$ узгоджена взаємодія ії структурних компонентів: цільового, законодавчо-нормативного, інституційного, організаційного, теоретикометодологічного, змістово-технологічного, діагностично-результативного. Через це, врахування провідних настанов та принципів андрагогічного підходу потрібно здійснювати вже на етапі проектування освітніх програм з певної спеціальності, в основі яких повинно бути закладене відповідне «бачення» особливостей протікання освітнього процесу.

Цільовий компонент професійної підготовки здобувачів вищої освіти містить мету й завдання, що спрямовані на забезпечення якісно нового рівня організації їхньої освітньої діяльності як майбутніх кваліфікованих, компетентних, мобільних та конкурентоздатних фахівців нової генерації, здатних до успішної адаптації та ефективної життєдіяльності в умовах глобалізаційних змін та соціокультурних перетворень. Реалізація провідної мети і окреслених завдань передбачає створення оптимальних умов для формування й розвитку загальних, професійних та спеціалізованих компетентностей, а також соціально й професійно важливих цінностей й якостей особистості, що сприятимуть цілеспрямованому використанню майбутніми фахівцями набутого впродовж навчання теоретичного та практичного потенціалу у процесі здійснення функцій фахової діяльності. Оскільки в умовах нестабільного функціонування сучасного ринку праці важливе значення має обізнаність випускників закладів вищої освіти із широким колом соціальних й етичних проблем, що супроводжують професійну діяльність фахівців в інформаційно насиченому й полікультурному середовищі, то особлива увага повинна бути сконцентрована на навчанні студентів різних прийомів комунікативної взаємодії 3 представниками різних культур та нестандартних способів виконання виробничих функцій із застосуванням інноваційних стратегій, новітніх засобів та технік (фасилітації, медіації, модерації, едвайзінгу [2]).

Законодавчо-нормативний компонент системи професійної підготовки здобувачів вищої освіти охоплює комплекс нормативно-правових документів (Конституція України, Закони України «Про освіту», «Про вищу освіту», «Про основи державної політики у сфері науки і науковотехнічної творчості», «Про наукову і науково-технічну діяльність», 238 
Національна доктрина розвитку освіти України у XXI столітті, «Про затвердження Національної рамки кваліфікацій», Національна стратегія розвитку освіти в Україні на період до 2025 року»), документи рекомендаційного характеру професійних організацій, асоціацій, об’єднань та ін. Особливістю національного законодавства в галузі вищої освіти $€$ наявність офіційних нормативних документів, які досить жорстко регламентують перелік кваліфікаційних напрямів підготовки майбутніх фахівців у закладах вищої освіти та організаційно-педагогічні засади освітнього процесу. Натомість навчання у закладах вищої освіти розуміється як важливий етап неперервного розвитку студентів як майбутніх фахівців, які, виявляючи свою дорослість та соціальну зрілість, мають можливість скористатися певними академічними свободами, успішно реалізувати власні соціокультурні, освітні й інтелектуальні потреби, долучившись до академічної мобільності й кар'єрного зростання.

Інституиійний компонент системи професійної підготовки здобувачів вищої освіти конкретизує типи й можливості певних освітніх установ, які, пройшовши процедури ліцензування й акредитації освітніх програм, спроможні забезпечити навчання майбутніх фахівців на першому - бакалаврському, другому - магістерському та третьому освітньо-науковому (доктор філософії) рівнях із присвоєнням відповідних ступенів. 3 огляду на це, підготовка бакалаврів, магістрів та докторів філософії за різними спеціальностями відбувається переважно в державних закладах вищої освіти III-IV рівнів акредитації, освітні програми яких, будучи заснованими на засадах андрагогічного підходу, враховують особливості періоду студентської юності на ранньої зрілості.

Організаиійний компонент професійної підготовки здобувачів вищої освіти відображає особливості реалізації іiі різних видів (теоретична, практична) та форм (денна, вечірня, заочна, дистанційна), а також способи забезпечення ефективності протікання освітнього процесу та шляхи, які зумовлюють досягнення якості прикінцевих результатів. При цьому слід враховувати, що в наступний час вища освіта $\epsilon$ багаторівневою (рівні: бакалаврський, магістерський, освітньонауковий) та ступеневою (освітні ступені: «Бакалавр», «Магістр», «Доктор філософії»). Організація професійної підготовки здобувачів вищої освіти останнім часом відбувається 3 врахуванням державних стандартів та Національної рамки кваліфікацій, згідно яких в освітніх програмах уточнюються інтегральні, загальні, професійні й фахові компетентності майбутніх фахівців як дорослих, які навчаються за певними спеціальностями, а також конкретизовані прикінцеві освітні 
результати за критеріями: знання та розуміння, практичні уміння й навички, здатність до комунікації, готовність до вияву автономності й відповідальності.

Теоретико-методологічний компонент системи професійної підготовки здобувачів вищої освіти зосереджений на соціальнофілософських, психолого-педагогічних та дидактичних теоріях, концепціях, підходах і принципах, що слугують світоглядним орієнтиром та концептуальною основою провадження освітньої діяльності. Серед них чільне місце належить андрагогічному підходу, який надає право суб'єктам освітнього процесу набути професійно й життєво необхідних компетенцій. Не випадково тому, вимоги сучасного суспільства знань до професійної діяльності та професійної компетентності майбутніх фахівців систематизовано в загальносуспільні, інформаційно-комунікативні, морально-етичні, індивідуально-психологічні, соціальнопрактичні, фахові блоки. Зумовлено це тим, що в умовах динамічного розвитку сучасного суспільства здобувачі вищої освіти, незалежно від спеціалізації професійної діяльності, мають сприяти його демократизації й забезпеченню національної безпеки, сприяти налагодженню ефективної комунікативної взаємодії представників різних культур, фасилітації процесів глобалізованої торгівлі та налагодженню міжнародних контактів тощо.

Змістово-технологічний компонент системи професійної підготовки здобувачів вищої освіти відбиває особливості їі предметно-наукового наповнення (шляхом формування навчального плану, який насичується переліком обов'язкових та вибіркових дисциплін, відповідних певної спеціальності), а також специфіку дидактико-методичного й інформаційно-технологічного інструментарію, необхідного для здійснення освітнього процесу та організації педагогічної взаємодії та комунікації провідних суб'єктів навчання. При цьому, вітчизняні заклади вищої освіти мають право самостійно обирати для впровадження певні освітні парадигми й технології, методи і форми навчання, способи організації навчальної, навчально-професійної та науково-дослідницької діяльності здобувачів. Серед них провідне місце має зайняти андрагогічна парадигма, суть якої полягає у проектуванні такого розвивального освітньо-наукового середовища, яке засновано на суб'єкт-суб'єктній взаємодії, що пробуджує здатність здобувачів діяти відповідно актуальній або перспективній освітній ситуації. Для цього суб'єкти, які здійснюють діяльність по викладанню навчальних дисциплін, повинні набути властивостей фахівців-андрагогів, здатних до виконання «рольових функцій консультанта, наставника, супервізора, модератора, фасилітатора, медіатора, тренера, коуча» [2, с. 129]. 240 
Діагностично-результативний компонент системи професійної підготовки здобувачів вищої освіти передбачає контроль, моніторинг й оцінювання результатів їхнього навчання на основі діагностування якості наданих закладом освітніх послуг, а також рівнів задоволеності ними студентів шляхом їхнього опитування, самооцінки продуктів освітньої діяльності.

\title{
Література:
}

1. Змеев С. И. Андрагогика: основы теории и технологии обучения взрослых. Москва : Персэ, 2003. 206 с.

2. Jarvis P. Adult Education and Lifelong Learning. Theory and practice. 3rd. edn. London: Routledge, 2004. 374 p.

DOI https://doi.org/10.30525/978-9934-588-80-8-2.64

\section{ОРГАНІЗАЦИЙОО-МЕТОДИЧНІ ЗАСАДИ СТВОРЕННЯ СПРИЯТЛИВИХ УМОВ ДЛЯ НАВЧАННЯ В ЗАКЛАДАХ ВИЩОЇ ОСВІТИ (ЗВО) СТУДЕНТІВ З ГЛИБОКИМИ ПОРУШЕННЯМИ ЗОРУ}

\author{
Серпутько Г. П. \\ кандидат філологічних наук, \\ доцент кафедри офтальмопедагогіки та офтальмопсихології \\ Наиіональний педагогічний університет імені М. П. Драгоманова \\ Гребенюк Т. М. \\ кандидат психологічних наук, \\ доцент кафедри офтальмопедагогіки та офтальмопсихології \\ Національний педагогічний університет імені М. П. Драгоманова \\ Федоренко М. I. \\ кандидат педагогічних наук, \\ доиент кафедри спеціальної психології та медицини \\ Начіональний педагогічний університет імені М. П. Драгоманова \\ м. Київ, Украӥна
}

На виконання вимог доступності до навчання осіб з інвалідністю, задекларованих у статті 24 «Освіта» Конвенції ООН про права осіб з інвалідністю, спрямоване й національне освітнє законодавство та низка підзаконних актів. 